\title{
EFFECTS OF HAMMER PEENING AND AGING TREATMENT ON MICROSTRUCTURE, MECHANICAL PROPERTIES AND CORROSION RESISTANCE OF OIL-GRADE ALLOY 718
}

\author{
Ting Chen ${ }^{1}$, Hendrik John² ${ }^{2}$ Jing Xü ${ }^{2}$ Jeffrey Hawk ${ }^{3}$, Xingbo Liu ${ }^{1}$ \\ ${ }^{1}$ Mechanical \& Aerospace Engineering Department, West Virginia University, Morgantown, WV 26506, USA \\ ${ }^{2}$ Baker Hughes Incorporated, Celle 29221, Germany \\ ${ }^{3}$ National Energy Technology Laboratory, Albany, OR 97321-2198
}

Keywords: Hammer Peening, Aging Treatment, Oil-Grade Alloy 718, Corrosion

\begin{abstract}
The effects of hammer peening and aging treatment on the near surface microstructure, mechanical properties, and corrosion resistance of oil-grade alloy 718 , were investigated. Milling and hammer peening treatments were performed on the surface of alloy 718 , followed by a double aging treatment. It was found that after aging treatment there were three distinguishable layers near the hammer-peened surface that had significantly different microstructures than the bulk material. On the top of the hammerpeened surface was a Cr-enriched oxide film. The second layer was a thin layer with high amount of $\gamma^{\prime} / \gamma^{\prime}$ ' nano-precipitations, and the one closest to the bulk material was a visible plastic deformation layer which was indicated by slip bands. It was also found that the micro-hardness significantly increased by hammer peening to the depth of about $1000 \mu \mathrm{m}$, however, aging treatment decreased the effective thickness to about $750 \mu \mathrm{m}$. Moreover, the surface compressive residual stresses were introduced by hammer peening but decreased after aging treatment. The effects of hammer peening and aging treatment on the corrosion resistance of oil-grade alloy 718 were also discussed in the final part of this paper.
\end{abstract}

\section{Introduction}

Oil-grade alloy 718 has been recently proposed for downhole drilling components in the oil and gas industry due to its superior mechanical properties and excellent corrosion resistance [1, 2]. As the wells become deeper the downhole pressures can reach over $20,000 \mathrm{psi}$ and temperatures increase to over $450^{\circ} \mathrm{F}$, requiring that the materials used for drilling equipment overcome significant challenges [3]. Both mechanical properties, like high strength and good toughness, and corrosion properties such as high pitting corrosion resistance, good environment assisted cracking (EAC) resistance and long corrosion fatigue life are required in the high pressure high temperature (HPHT), $\mathrm{H}_{2} \mathrm{~S}, \mathrm{CO}_{2}$ and chloridecontaining harsh corrosive oil field environments [4]. Since many modern drilling and production applications are in deep seawater environments, the high-choride-content aqueous drilling fluids could lead to pitting corrosion, crevice corrosion or stress corrosion cracking. Therefore, localized corrosion properties such as the pitting corrosion property of oil-grade alloy 718 used in deep wells drilling became a very important motivation for its use in such conditions. In addition, hammer peening is a surface treatment process that has been used to improve the corrosion fatigue resistance of alloys by introducing deep compressive residual stress profiles [5]. However, the effects of hammer peening surface treatment on the pitting corrosion resistance of alloys have not been widely investigated and are not fully understood yet.
The objective of this study is to investigate the effects of hammer peening and aging treatment on the near surface microstructure, mechanical properties, and corrosion resistance of oil-grade alloy 718 in $3.5 \mathrm{wt} \% \mathrm{NaCl}$ solution at room temperature.

\section{Material and Specimens}

The oil-grade alloy 718 used in this study was supplied by Baker Hughes Incorporated and its chemical compositions are shown in Table 1.

Table 1 Chemical compositions of oil-grade alloy 718

\begin{tabular}{|c|c|c|c|c|c|c|c|c|}
\hline Element & $\mathrm{C}$ & $\mathrm{Ni}$ & $\mathrm{Cr}$ & $\mathrm{Fe}$ & $\mathrm{Nb}$ & $\mathrm{Mo}$ & $\mathrm{Ti}$ & $\mathrm{Al}$ \\
\hline $\mathrm{wt} \%$ & 0.02 & 52.6 & 18.5 & Balance & 5.1 & 3.0 & 1.0 & 0.5 \\
\hline
\end{tabular}

The as-received alloy was annealing solution treated at $1032^{\circ} \mathrm{C}$ $\left(1890^{\circ} \mathrm{F}\right)$ for $2 \mathrm{~h}$ by the vender. After the annealing solution, the alloy was milled and hammer-peened. During high frequency hammer peening surface treatment, Tungsten Carbide (TC)-balls with diameters of $8 \mathrm{~mm}$ were used with a frequency of $140 \mathrm{~Hz}$ on one side of the milled surface with a rate of $4 \mathrm{~m} / \mathrm{min}$. Then the alloy was cut into two pieces and one piece was double aged at the temperatures of $760^{\circ} \mathrm{C}\left(1400{ }^{\circ} \mathrm{F}\right)$ for $4 \sim 5 \mathrm{~h}$ and $650^{\circ} \mathrm{C}(1202$ $\left.{ }^{\circ} \mathrm{F}\right)$ for $4 \sim 5 \mathrm{~h}$. The detailed samples information is listed in Table 2 .

Table 2 Surface treatment and aging treatment conditions

\begin{tabular}{|l|l|}
\hline 1\# & $1032^{\circ} \mathrm{C}\left(1890^{\circ} \mathrm{F}\right) / 2 \mathrm{~h}+$ Milling \\
\hline 2\# & $\begin{array}{l}1032^{\circ} \mathrm{C}\left(1890^{\circ} \mathrm{F}\right) / 2 \mathrm{~h}+\text { Milling }+760^{\circ} \mathrm{C}\left(1400^{\circ} \mathrm{F}\right) / 4 \sim 5 \mathrm{~h}+ \\
650^{\circ} \mathrm{C}\left(1202^{\circ} \mathrm{F}\right) / 4 \sim 5 \mathrm{~h}\end{array}$ \\
\hline 3\# & $1032^{\circ} \mathrm{C}\left(1890^{\circ} \mathrm{F}\right) / 2 \mathrm{~h}+$ Milling + Hammer Peening \\
\hline $4 \#$ & $\begin{array}{l}1032^{\circ} \mathrm{C}\left(1890^{\circ} \mathrm{F}\right) / 2 \mathrm{~h}+\text { Milling }+ \text { Hammer Peening }+760 \\
{ }^{\circ} \mathrm{C}\left(1400^{\circ} \mathrm{F}\right) / 4 \sim 5 \mathrm{~h}+650^{\circ} \mathrm{C}\left(1202^{\circ} \mathrm{F}\right) / 4 \sim 5 \mathrm{~h}\end{array}$ \\
\hline
\end{tabular}

Experimental Tests

\section{Micro-Hardness Test}

Vickers micro-hardness tests conforming to the ASTM E384-05 standard were performed with a force of $0.3 \mathrm{~N}(300 \mathrm{~g})$ for $15 \mathrm{~s}$ on the surfaces and cross-sections of specimens. An average of ten measurements was used for each data point.

\section{$\underline{\text { Residual Stress Measurement }}$}

Residual stresses on the surface of milled and hammer-peened samples were measured by XRD according to the $\sin ^{2} \Psi$ method. 


\section{Microstructure Characterization}

The surface and near surface microstructure of all the specimens were examined using optical microscopy (OM) and scanning electron microscopy (SEM). Cross-section specimens mounted in epoxy were mechanical ground by $120 \sim 1000$ grit silicon carbide waterproof paper and polished using polishing cloth with $3 \mu \mathrm{m}$ and $1 \mu \mathrm{m}$ diamond suspension, followed by chemical etching with a mixture of $200 \mathrm{ml}$ methanol, $200 \mathrm{ml}$ hydrochloric acid and $10 \mathrm{~g}$ $\mathrm{CuCl}_{2}$ for $4 \mathrm{~min}$.

\section{$\underline{\text { Surface Analysis }}$}

X-ray photoelectron spectroscopy (XPS) analysis was carried out using a PHI 5000 VersaProbe system with a monochromatic AlKa radiation source to examine the oxide films formed on the unaged and aged hammer-peened surface, respectively. The C1s peak from contaminative carbon at $284.8 \mathrm{eV}$ was used as a reference to correct the charging shifts. Depth profiling of oxide films was performed using argon ions bombardment with an ion energy of 2 $\mathrm{kV}$. The sputtering rate was estimated to be about $12 \mathrm{~nm} / \mathrm{min}$.

\section{Electrochemical Tests}

For the electrochemical tests, all the specimens were mounted using epoxy leaving only $0.5 \mathrm{~cm} * 0.5 \mathrm{~cm}$ of the milled or hammer-peened surface exposed, rinsed with distilled water, dried in air at room temperature and then transferred to the test solution. All electrochemical tests were carried out in a standard three electrode system in a $1.5 \mathrm{~L}$ glass cell. A three-electrode cell setup consisting of a pair of graphite counter electrodes, a saturated calomel electrode (SCE) reference electrode and specimen as working electrode was employed. Potentiodynamic polarization curves for the surface of the samples with milling or hammer peening were carried out at room temperature in $3.5 \mathrm{wt} \% \mathrm{NaCl}$ solution. At the beginning of each experiment, the working electrode was first cathodically polarized at $-1 \mathrm{~V}$ vs. SCE for 10 min to remove air-formed surface oxides and then immersed in the test solution for $1 \mathrm{~h}$ to attain a stable value of open-circuit potential (OCP). Potentiodynamic polarization curves were performed with a Solartron SI 1287 electrochemical interface. For this series of tests, the samples were conducted from $-0.5 \mathrm{~V}$ vs. SCE towards the anodic direction at a scanning rate of $0.5 \mathrm{mV} / \mathrm{s}$ after measuring the OCP for $1 \mathrm{~h}$.

\section{Results and Discussion}

\section{Mechanical Properties}

The surface hardnesses of all the specimens are shown in Table 3.

Table 3 Surface conditions of oil-grade alloy 718

\begin{tabular}{|c|c|c|c|}
\hline Samples & $\begin{array}{c}\text { Hardness } \\
(\mathrm{HV})\end{array}$ & $\begin{array}{c}\text { Residual Stress } \\
(\mathrm{MPa})\end{array}$ & $\begin{array}{c}\text { Roughness } \\
(\mu \mathrm{m})\end{array}$ \\
\hline $1 \#$ & 260 & -190 & 43.61 \\
\hline $2 \#$ & 420 & -95 & 23.68 \\
\hline $3 \#$ & 340 & -730 & 9.04 \\
\hline $4 \#$ & 450 & -115 & 9.66 \\
\hline
\end{tabular}

After hammer peening the surface hardness of unaged alloy 718 is higher than the original milled specimen by $80 \mathrm{HV}$. This may be due to the increase of dislocation density that the work hardening of surface layer was increased. Moreover, the surface hardness was increased by aging treatment because of the formation of $\gamma^{\prime} / \gamma^{\prime \prime}$ precipitations.

Furthermore, micro-hardness tests were performed on the crosssections of the specimens in order to determine the hardness of layers and depth of hardening. The hardness values versus distance from the surface of specimen are presented in Fig. 1.

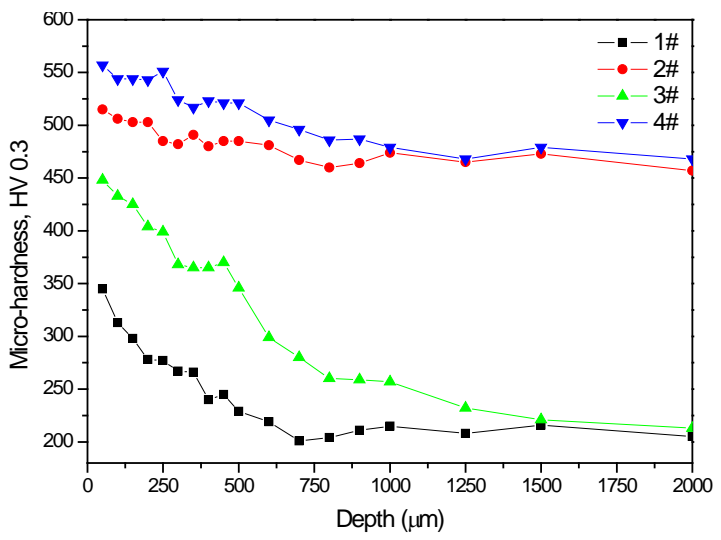

Fig. 1 Micro-hardness depth profile of oil-grade alloy 718

The micro-hardness depth profile illustrates that the hardness of unaged alloy 718 was decreased with increasing the depth from the surface into the bulk material, which means that the microhardness was increased by milling and hammer peening surface treatments. Also, it can be seen that the hardness of hammerpeened surface region was higher than milled surface region and the hardness decreased with a sharp slope until the depth of 1000 and $500 \mu \mathrm{m}$ respectively, with respect to the surface of the two specimens. After these depths, no considerable variations were observed and constant behaviors were shown for hardness. This hardness increase of the specimen's surface and near surface region and its gradual decrease shows the presence of compressive residual stresses and work hardening. It was also found that the hardness significantly increased after aging treatment due to the formation of $\gamma^{\prime} / \gamma^{\prime}$ ' precipitations. Furthermore, the hardness of aged alloy 718 decreased with a moderate slope until the depth of 750 and $300 \mu \mathrm{m}$ respectively, which means that the aging treatment could weaken the effect of work hardening and decreased the compressive residual stresses values.

Table 3 shows the surface residual stress values of the four specimens. It can be seen that compressive residual stresses were produced due to the milling and hammer peening surface treatments. The absolute value of the compressive residual stress of the unaged hammer-peened sample was significantly increased compared with the original milled one, while after aging treatment the residual stresses were decreased in both the milled and hammer-peened specimens.

\section{Microstructure}

The SEM images taken of the surfaces of specimens are presented in Fig. 2(a d). It can be seen that surface marks and cracks were produced by the milling process. However, the hammer peening treatment produced a smoother surface with a slightly decreased roughness. 


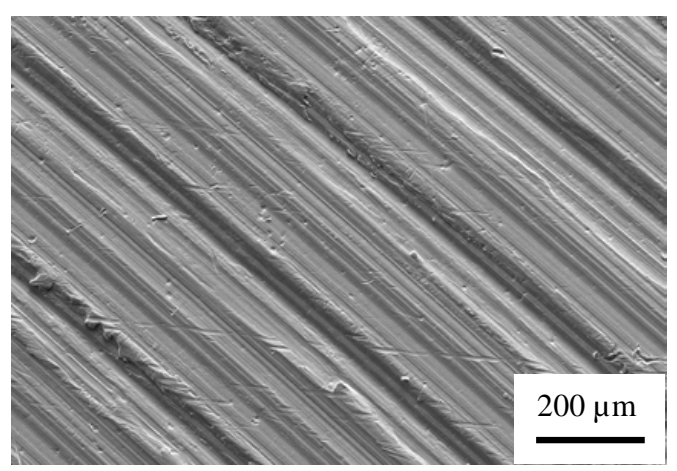

(a)

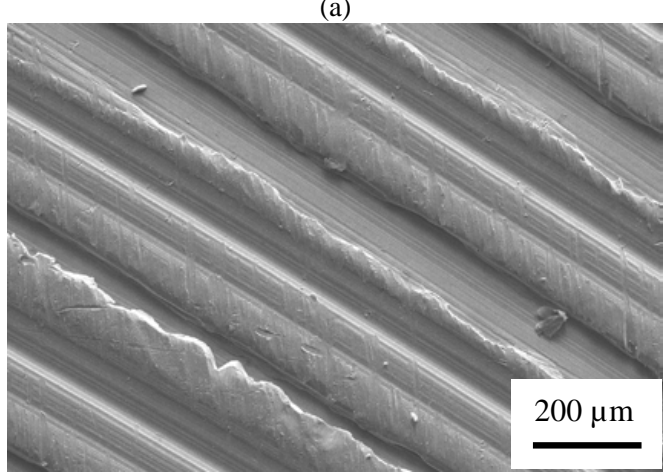

(b)

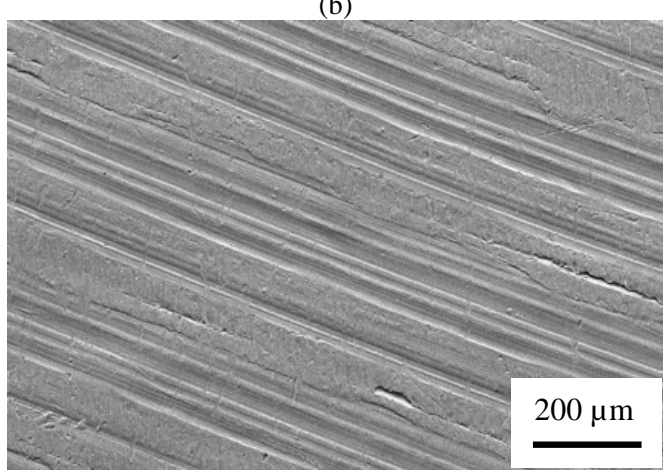

(c)

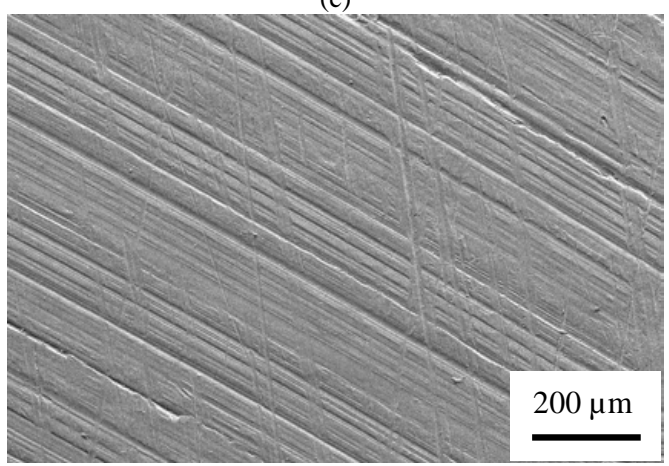

(d)

Fig. 2 Surface morphologies of oil-grade alloy 718: (a) 1\#, (b) 2\#, (c) 3\#, (d) 4\#

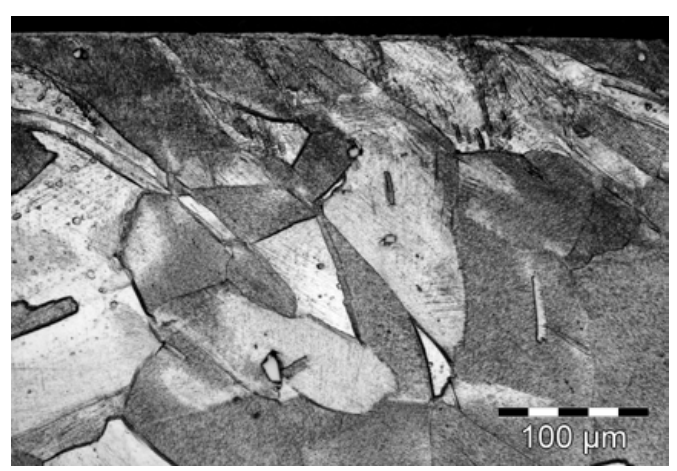

(a)

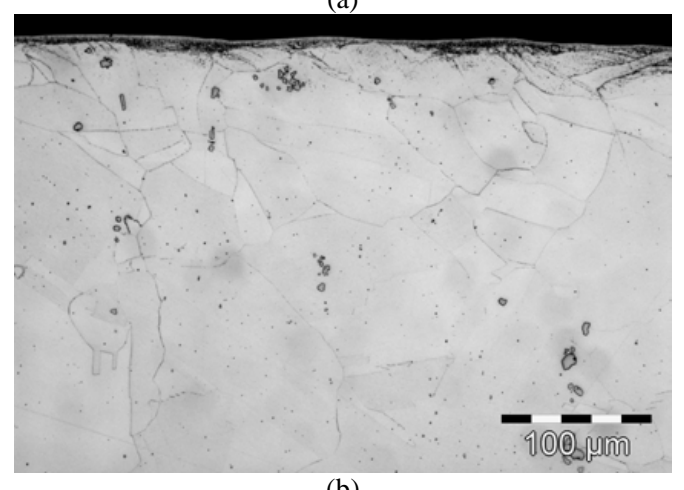

(b)

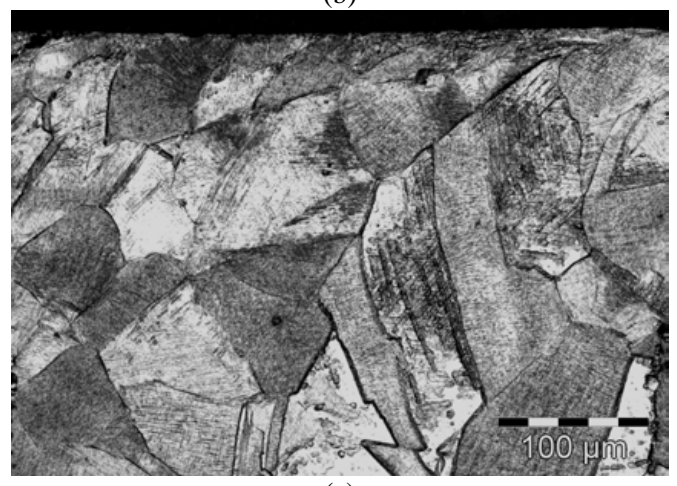

(c)

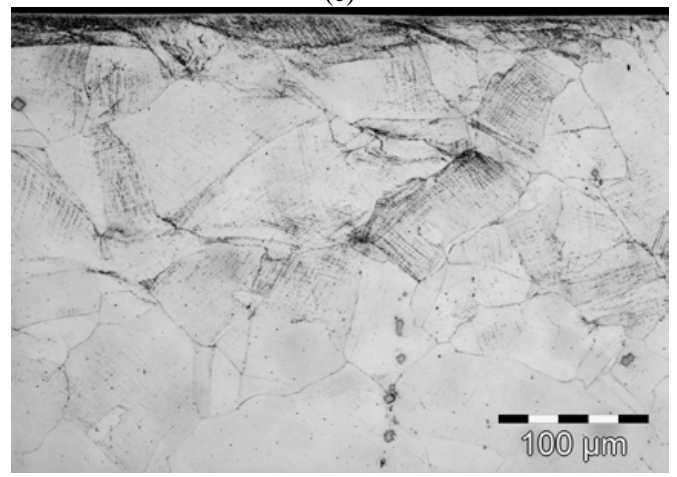

(d)

Fig. 3 Optical micrographs for the near surface cross-section microstructure of oil-grade alloy 718: (a) 1\#, (b) 2\#, (c) 3\#, (d) 4\# 


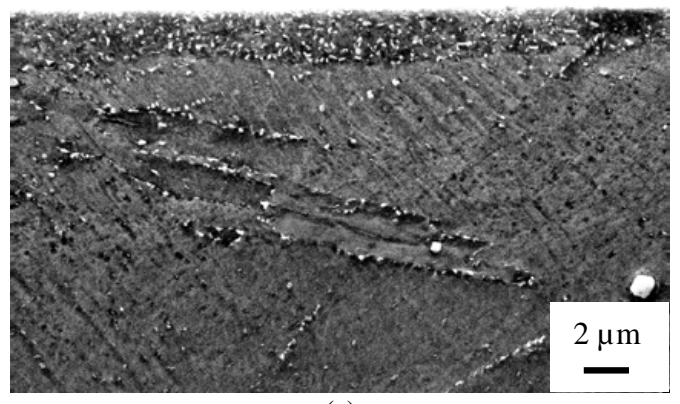

(a)

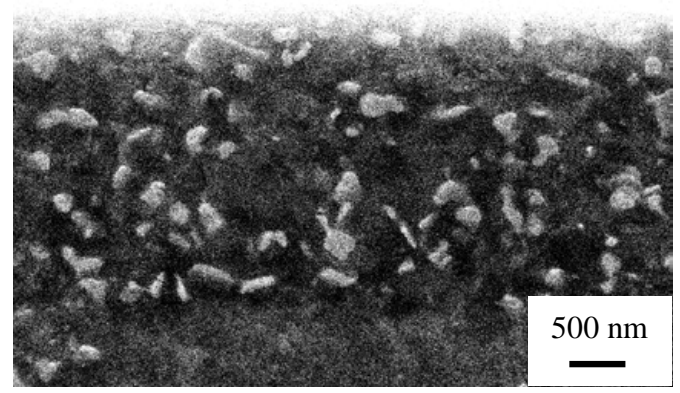

(b)

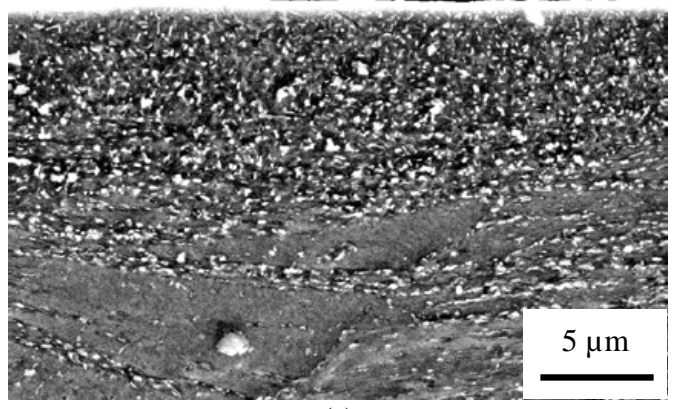

(c)

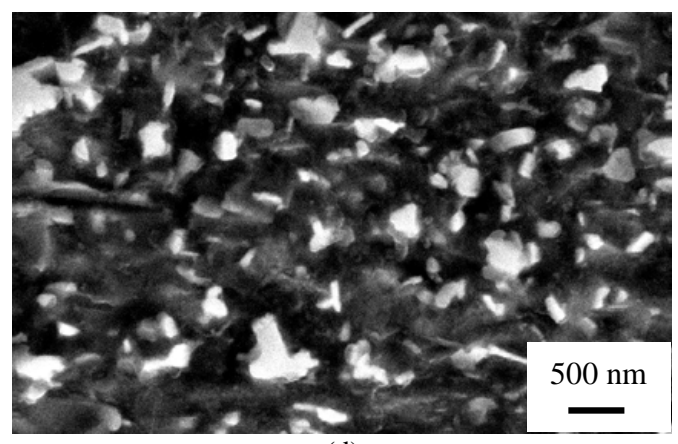

(d)

Fig. 4 SEM images for the near surface cross-section microstructure of oil-grade alloy 718 after aging treatment: (a) 2\#, (b) 2\# (high magnification), (c) 4\#, (d) 4\# (high magnification)
Surface roughness tests were performed on the surfaces of the milled and hammer-peened samples. The surface roughness and homogeneity are very influential in passive layer formation and, therefore, in corrosion resistance of alloys. The roughness values are presented in Table 3. As shown in Fig. 2 and Table 3, the surface roughness was decreased after hammer peening treatment.

Fig. 3(a d) are optical micrographs of the near surface crosssection microstructure of all the specimens. It was found that that a visible plastic deformation layer, which was about $100 \mu \mathrm{m}$ and indicated by slip bands, was generated by milling process (Fig. 3(a)). In the hammer-peened specimen, the thickness of the plastically deformed layer was formed to about $250 \mu \mathrm{m}$ (Fig. 3 (c)). After aging treatment, the thickness of deformed layer of milled and hammer-peened alloy 718 was decreased.

More detailed microstructural features of aged alloy 718 samples were observed using SEM and shown in Fig. 4 (a d). It can be seen that a thin layer with high amount of precipitations was introduced close to the alloy surface and the thickness of the precipitation layer was increased from about 2 to $10 \mu \mathrm{m}$ after hammer peening surface treatment (Fig. 4 (a, c)). The high magnification SEM images of the precipitation layer showed that these precipitates were in the size of about $150 \sim 300 \mathrm{~nm}$, which might be corresponding to $\gamma^{\prime} / \gamma^{\prime \prime}$ phases [2].

\section{$\underline{\text { XPS Analysis }}$}

XPS analysis was carried out to examine the oxide films that were formed on the hammer-peened surface before and after the aging treatment. The XPS survey scan peaks for hammer-peened oilgrade alloy 718 samples before sputtering and after 1 min sputtering are shown in Fig. 5.

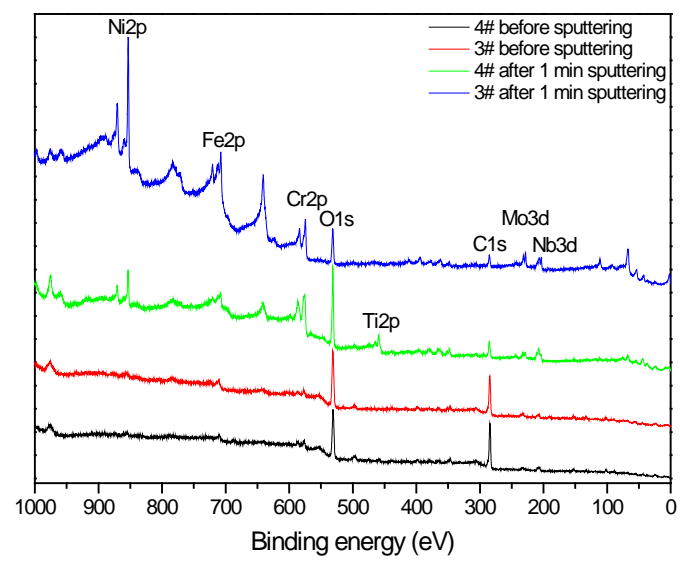

Fig. 5 XPS spectrum of hammer-peened oil-grade alloy 718.

C1s, O1s, Cr2p, Nb3d and Mo3d peaks can be seen in both unaged and aged conditions before sputtering. The appearance of Ti2p peaks in surface oxide film of aged hammer peening samples indicates the existence of Ti oxide. After 1 min sputtering, the peaks of Ni2p and Fe2p have been detected in the spectra. The atomic concentration of chemical species in the surface oxide layers before sputtering was illustrated in Table 4 according to the fitted XPS detailed peaks. The XPS results indicated double-layer structure of the oxide film and showed that the surface layer was mainly Cr-enriched oxide. 
Table 4 Atomic concentration (\%) of chemical species in the surface oxide layers of hammer-peened oil-grade alloy 718

\begin{tabular}{|l|l|l|l|l|l|l|}
\hline Samples & $\mathrm{Cr}$ & $\mathrm{Fe}$ & $\mathrm{Ni}$ & $\mathrm{Nb}$ & $\mathrm{Mo}$ & $\mathrm{Ti}$ \\
\hline $3 \#$ & 64.2 & 0 & 0 & 16.4 & 19.4 & 0 \\
\hline $4 \#$ & 51.2 & 0 & 0 & 12.7 & 7.4 & 28.7 \\
\hline
\end{tabular}

In order to compare the thickness of the oxide film formed on the surface of oil-grade alloy 718 before and after aging treatment, XPS depth profiling for $\mathrm{Cr}$ oxide films formed on the surface of hammer-peened oil-grade alloy 718 specimens was carried out and illuminated in Fig. 6. It was clear that the thickness of the surface oxide film was increased from 30 to $100 \mathrm{~nm}$ after aging treatment because the sputtering rate was estimated to be about 12 $\mathrm{nm} / \mathrm{min}$.

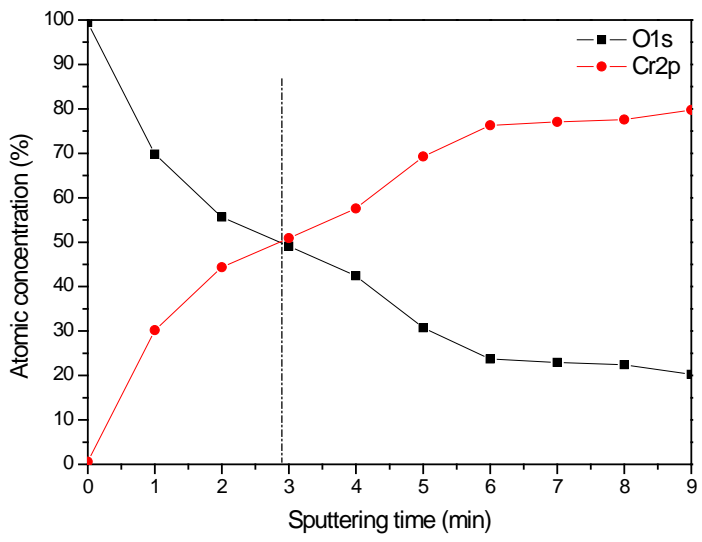

(a)

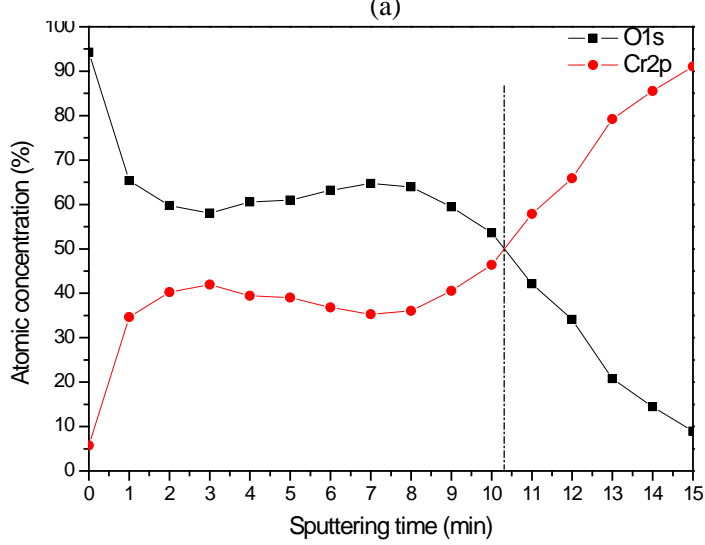

(b)

Fig. 6 XPS depth profiling of Cr-enriched oxide film formed on the surface of hammer-peened oil-grade alloy 718: (a) 3\#, (b) 4\#

(Note: these sputtering times were used to estimate oxide depths with a sputtering rate estimated to be $12 \mathrm{~nm} / \mathrm{min}$ )

\section{Corrosion Behavior}

The corrosion potential, corrosion current density, passive current density and pitting potential of each specimen were determined from potentiodynamic polarization curves shown in Fig. 7 and the results are listed in Table 5. After hammer peening, the corrosion current density and passive current density of unaged oil-grade alloy 718 decreased, and the corrosion potential shifted to less negative direction, compared to those of the original milled specimen. The smaller values of corrosion current density and passive current density indicate higher corrosion resistance. Therefore, the hammer peening treatment could improve corrosion resistance of oil-grade alloy 718 in unaged conditions. After aging treatment, the corrosion current density and passive current density of milled or hammer-peened specimen were decreased, and the corrosion potential shifted to less negative direction, compared to those of unaged samples. This may be attributed to the formation of the thicker oxide films. Also, in both aged and unaged conditions, the pitting potentials of the hammerpeened specimens were higher than the milled ones, which indicated higher localized corrosion resistance. Therefore, the results showed that the pitting corrosion resistance of oil-grade alloy 718 could be improved by hammer peening surface treatment.

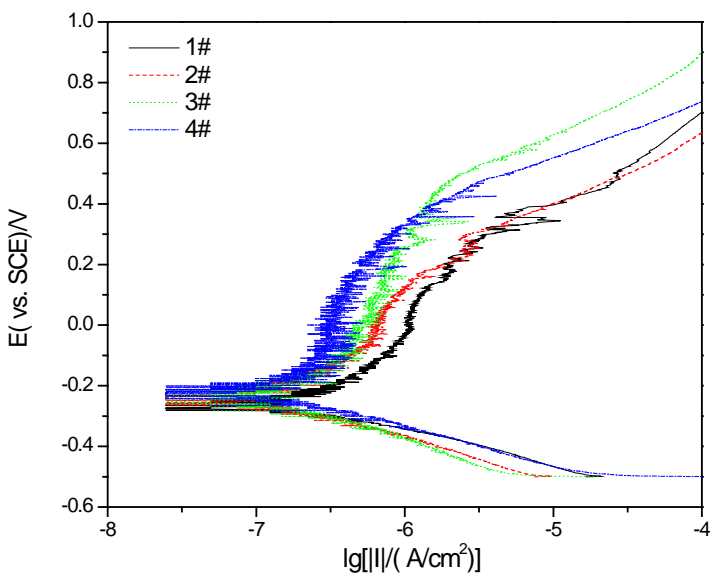

Fig. 7 Potentiodynamic polarization curves of surface-treated oilgrade alloy 718 before grinding in $3.5 \mathrm{wt} \% \mathrm{NaCl}$ at Room Temperature (RT)

Table 5 Potentiodynamic polarization results of surface-treated oil-grade alloy 718 before grinding in $3.5 \mathrm{wt} \% \mathrm{NaCl}$ at RT

\begin{tabular}{|c|c|c|c|c|}
\hline Samples & $\begin{array}{c}\mathrm{E}_{\text {corr }} \\
\left(\mathrm{V}_{\mathrm{SCE}}\right)\end{array}$ & $\begin{array}{c}\mathrm{I}_{\text {corr }} \\
\left(\mathrm{A} / \mathrm{cm}^{2}\right)\end{array}$ & $\begin{array}{c}\mathrm{I}_{\text {pass }} \\
\left(\mathrm{A} / \mathrm{cm}^{2}\right)\end{array}$ & $\begin{array}{c}\mathrm{E}_{\text {pit }} \\
\left(\mathrm{V}_{\mathrm{SCE}}\right)\end{array}$ \\
\hline $1 \#$ & -0.272 & $1.70 \mathrm{E}-7$ & $1.25 \mathrm{E}-6$ & 0.298 \\
\hline $2 \#$ & -0.232 & $9.20 \mathrm{E}-8$ & $9.16 \mathrm{E}-7$ & 0.298 \\
\hline $3 \#$ & -0.249 & $9.68 \mathrm{E}-8$ & $6.68 \mathrm{E}-7$ & 0.494 \\
\hline $4 \#$ & -0.219 & $9.86 \mathrm{E}-8$ & $4.13 \mathrm{E}-7$ & 0.457 \\
\hline
\end{tabular}

Many factors, such as surface treatment method, surface roughness, surface oxide layer, grain size, residual stress etc. can affect the corrosion behavior of alloys [6 8]. In this study, two different surface treatments were applied to the surface of oilgrade alloy 718 . First, different surface roughness produced by different surface treatment may influence the corrosion properties. The surface roughness results showed that hammer-peened specimens had a slightly lower surface roughness than the original milled samples. It was reported that corrosion resistance is inversely proportional to the surface roughness [6]. Therefore, the reason that the hammer-peened specimens had better corrosion resistance may be that the surface roughness was decreased. Secondly, the thickness and chemical composition of surface oxide layer also may affect the corrosion resistance of oil-grade alloy 718. According to the XPS analysis, the oxide films formed on the aged oil-grade alloy 718 samples were thicker and denser 
compared to those formed on the unaged ones, which may result in higher passive current density and better corrosion resistance. In order to avoid the effects of surface roughness and surface oxide layer, and to determine the influence of compressive residual stress on the corrosion behavior of oil-grade alloy 718 , the surface of four specimens were ground with 600 grit $\mathrm{SiC}$ paper to a depth of about $2 \mu \mathrm{m}$, and then the same potentiodynamic polarization measurement was performed again. Fig. 8 shows the polarization curves of oil-grade alloy 718 samples after surface grinding. The polarization parameters results are listed in Table 6. For unaged oil-grade alloy 718 samples, the corrosion current density and the passive current density decreased, and the corrosion potential and the pitting potential shifted towards less negative direction after hammer peening, which means that compressive residual stress induced by hammer peening treatment could improve corrosion resistance of oil-grade alloy 718. For milled or hammer-peened specimens after aging treatment, the corrosion current density and passive current density were decreased, and the corrosion potential and the pitting potential increased compared to the unaged milled oil-grade alloy 718. However, it was found that the compressive residual stress value of unaged milled specimen was higher than the aged milled or aged hammer-peened ones. This may be due to the formation of a precipitation layer that assumed to be $\gamma^{\prime} / \gamma^{\prime \prime}$ phases [2] close to the top of the surface, resulting in better corrosion resistance.

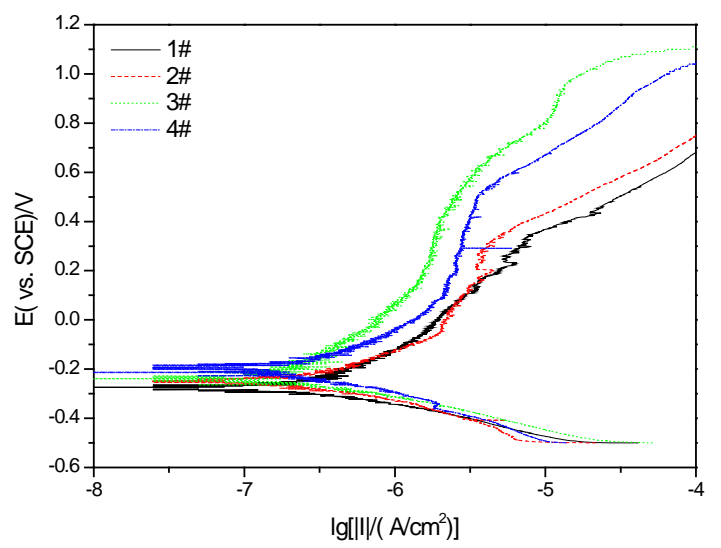

Fig. 8 Potentiodynamic polarization curves of surface-treated oilgrade alloy 718 after grinding in $3.5 \mathrm{wt} \% \mathrm{NaCl}$ at $\mathrm{RT}$

Table 6 Potentiodynamic polarization results of surface-treated oil-grade alloy 718 after grinding in $3.5 \mathrm{wt} \% \mathrm{NaCl}$ at $\mathrm{RT}$

\begin{tabular}{|c|c|c|c|c|}
\hline Samples & $\begin{array}{c}\mathrm{E}_{\text {corr }} \\
\left(\mathrm{V}_{\text {SCE }}\right)\end{array}$ & $\begin{array}{c}\mathrm{I}_{\text {corr }} \\
\left(\mathrm{A} / \mathrm{cm}^{2}\right)\end{array}$ & $\begin{array}{c}\mathrm{I}_{\text {pass }} \\
\left(\mathrm{A} / \mathrm{cm}^{2}\right)\end{array}$ & $\begin{array}{c}\mathrm{E}_{\text {pit }} \\
\left(\mathrm{V}_{\text {SCE }}\right)\end{array}$ \\
\hline $1 \#$ & -0.277 & $2.63 \mathrm{E}-7$ & $3.08 \mathrm{E}-6$ & 0.288 \\
\hline $2 \#$ & -0.251 & $2.50 \mathrm{E}-7$ & $2.82 \mathrm{E}-6$ & 0.321 \\
\hline $3 \#$ & -0.239 & $1.58 \mathrm{E}-7$ & $1.18 \mathrm{E}-6$ & 0.671 \\
\hline $4 \#$ & -0.206 & $1.95 \mathrm{E}-7$ & $2.08 \mathrm{E}-6$ & 0.528 \\
\hline
\end{tabular}

\section{Conclusions}

Based on the results obtained from this research, several conclusions can be drawn:

(1) A Cr-enriched oxide film (about $100 \mathrm{~nm}$ ), a thin layer of precipitations (about $10 \mu \mathrm{m}$ ) that assumed to be $\gamma^{\prime} / \gamma^{\prime \prime}$ and a visible heavy deformed layer (about $250 \mu \mathrm{m}$ ) indicated by slip bands were produced by hammer peening and aging treatment for oil-grade alloy 718 .

(2) The hardness of oil-grade alloy 718 was increased by hammer peening to the depth of about $1000 \mu \mathrm{m}$, however, aging treatment decreased the effective thickness to about $750 \mu \mathrm{m}$.

(3) Hammer peening surface treatment can produce compressive residual stresses and the absolute values of compressive residual stress were decreased after aging treatment.

(4) Compressive residual stresses introduced by hammer peening surface treatment can significantly increase the corrosion resistance of oil-grade alloy 718 in $3.5 \mathrm{wt} \% \mathrm{NaCl}$ solution at room temperature. Also, the precipitations layer of $\gamma^{\prime} / \gamma^{\prime}$ ' phases close to the top of the surface, which was produced by aging treatment, can improve the corrosion resistance of oil-grade alloy 718 .

\section{Acknowledgement}

This technical effort was performed in support of the National Energy Technology Laboratory's ongoing research in materials for ultra-deep drilling under the RES contract DE-FE000400.

\section{Reference}

[1] O.A. Onyewuenyi. "ALLOY 718-ALLOY OPTIMIZATION FOR APPLICATIONS IN OIL AND GAS PRODUCTION", Superalloy 718-Metallurgy and Applications, ed. Edward A. Loria, (Warrendale, PA: The Minerals, Metals \& Materials Society, 1989), 345-362.

[2] J. Kolts. "ALLOY 718 FOR THE OIL AND GAS INDUSTRY”, Superalloy 718-Metallurgy and Applications, ed. Edward A. Loria, (Warrendale, PA: The Minerals, Metals \& Materials Society, 1989), 329-344.

[3] M.L. Payne et al., "Advanced Technology Solutions for Next Generation HPHT Wells" (Paper presented at the International Petroleum Technology Conference, Dubai, U.A.E, 4-6 December 2007).

[4] J.K. Brownlee et al., "Selection and Qualification of Materials for HPHT Wells" (Paper presented at the SPE High Pressure-High Temperature Sour Well Design Applied Technology Workshop, The Woodlands, Texas, 17-19 May 2005).

[5] I.E. Kopsov, "The influence of hammer peening on fatigue in high-strength steel”, International Journal of Fatigue, 13 (6) (1991), 479-482.

[6] H. Lee et al., "Influence of peening on the corrosion resistance of AISI 304 stainless steel”, Corrosion Science, 51 (2009), 28262830.

[7] V. Azar, B. Hashemi, and M.R. Yazdi, "The effect of shot peening on fatigue and corrosion behavior of 316L stainless steel in Ringer's solution”, Surface \& Coatings Technology, 204 (2010), 3546-3551.

[8]TS. Wang, JK. Yu, and BF. Dong, "Surface nanocrystallization induced by shot peening and its effect on corrosion resistance of 1Cr18Ni9Ti stainless steel"', Surface \& Coatings Technology, 200 (2006), 4777-4781. 